๑ Entomologica Fennica. 22 October 2001

\title{
A new Gyrinus species from Mongolia (Coleoptera: Gyrinidae)
}

\author{
Anders N. Nilsson
}

Nilsson, A. N. 2001: A new Gyrinus species from Mongolia (Coleoptera: Gyrinidae). — Entomol. Fennica 12: 121-124.

A new species of Gyrinus O. F. Müller (Coleoptera: Gyrinidae) is described from Mongolia: G. sugunurensis. The new species was earlier confused with G. distinctus Aubé.

Anders N. Nilsson, Department of Biology and Environmental Science, SE90187 Umeå University, Sweden; E-mail: Anders.Nilsson@bmg.umu.se

Received 21 February 2001, accepted 23 July 2001

\section{Introduction}

In his review of Mongolian Gyrinidae, Guéorguiev (1968) included the following seven species: Aulonogyrus concinnus (Klug); Gyrinus minutus Fabricius, 1798; G. paykulli Ochs, 1927; G. distinctus Aubé, 1838; G. marinus Gyllenhal, 1808; G. aeratus Stephens, 1835; and G. opacus C. R. Sahlberg, 1819. Later, Guéorguiev (1969, 1972) added one more record each from Mongolia of G. aeratus and G. distinctus. The examination of some unidentified Asian Gyrinus specimens in the Zoological Institute of St. Petersburg revealed the presence of one more species in Mongolia, which will be described here as new. The new species is very similar to $G$. distinctus, with which it will be compared. Moreover, the single female of $G$. distinctus recorded from UlanBaator by Guéorguiev (1968) in fact belongs to the new species.

\section{Material and species descriptions}

The material studied belong to the collections below, which are referred to in the text by the following abbreviations:

TMB .............. Természettudományi Múzeum, Budapest ZISP Zoological Institute, St. Petersburg

\section{Gyrinus distinctus Aubé}

Gyrinus distinctus Aubé, 1838:383 (orig. descr.: Europe, Barbarie \& Égypte); Zimmermann 1917: 158 (syn.).

Gyrinus niloticus Waltl, 1838:453 (orig. descr.: Balkan \& Egypten). Égypte)

Gyrinus aegyptiacus Régimbart, 1883:155 (orig. descr.:

Gyrinus fairmairei Régimbart, 1883:144 (orig. descr.: Mésopotamie, Bagdad); Zimmermann 1926:98 (syn.).

Gyrinus hungaricus Seidlitz, 1887: 131 (orig. descr.: Hungaria et Transsylvania).

Gyrinus atlanticus Régimbart, 1892:678 (orig. descr.: Açores).

Gyrinus fulviventris Reitter, 1908:236 (orig. descr.: Syria, Akbes).

Gyrinus atlanticus guernei Méquignon, 1942a:9 (orig. descr.: Açores, Flores), 1942b:15 (descr.).

Studied material: Mongolia, Dzabkhan province,

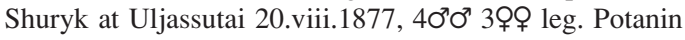
(ZISP); Russia, Krasnodarsk district, Madesta, 14.viii.1997, $10^{\text {T}}$ leg. D. Feodorov; Volgograd district, Volgograd, 9.v.2001, $10^{\top 1} 1$ ㅇ leg. A. Nilsson; Sweden, Halland, Getterön,

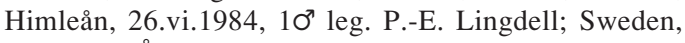
Medelpad, Åstön, 25.vi.1999, $10^{7}$ leg. A. Nilsson (CNU).

The taxonomy of this species is quite confusing as it was not separated from G. colymbus Erichson, 1837 for a long period of time (e.g. Balfour-Browne 1950). However, already Zimmermann (1917) made a clear distinction between the two species as he, following Sharp (1914), introduced penis shape as an important diagnostic character within the genus Gyrinus. As currently known, G. distinctus is widespread, being known from the British Isles and Fennoscandia to Kashmir and China, and southwards to the 


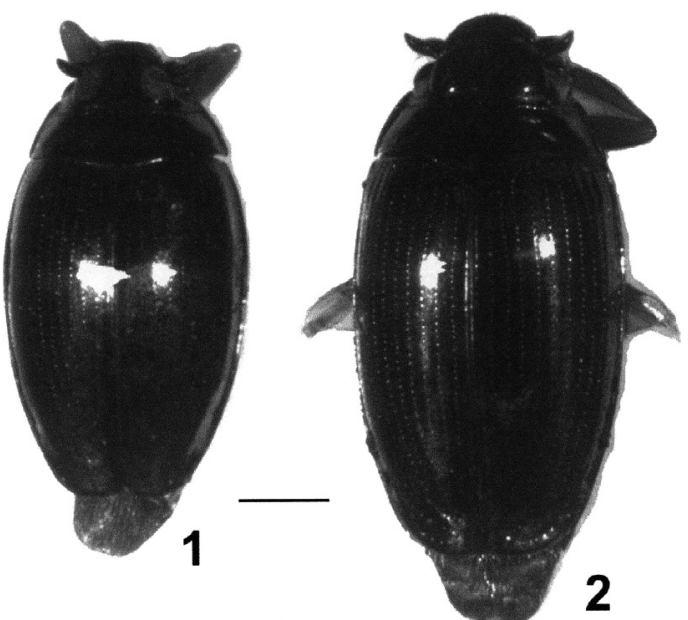

Figs. 1-2. Gyrinus, dorsal habitus of male. - 1. G. sugunurensis sp. n., paratype. - 2. G. distinctus Aubé, Volgograd. Scale bar $1 \mathrm{~mm}$.

Azores, Egypt and Sudan (Svensson 1977, Holmen 1987). The most important variation displayed by G. distinctus is the ventral colour which is more yellow towards the southeast (var. fairmairei Régimbart; Ochs 1953). Males of this species are characterized by the very wide, spoon-shaped penis (Holmen 1987).

\section{Gyrinus sugunurensis n. sp.}

Gyrinus distinctus Aubé, 1838: Guéorguiev 1968:25 (misident.).

Type locality: Mongolia, Central Province, Kentei Mountains, Haara Gol river system, tributary Sugu Nur.

Type material: Holotype $0^{7}$ in ZISP labelled (here transcribed from Cyrillic): "r. Sugu-nur, Verkh. Khara-gula, Kent., Kozlov 17-21.vi.924”, and my holotype label. Paratypes $50^{\circ} 0^{\circ} 4$ 우 in ZISP and CNU with same locality label and dates 6-11.vi, 17-21.vi \& 2-4.vii; 1 \% in TMB labelled: "Mongolia: Central aimak, Ulan-Baator, in der Stadt, 1350m Exp.Dr.Z.Kaszab, 1965”, “Nr. 490, 30.VIII.1965", and my paratype label.

Diagnosis: The new species is similar to G. distinctus from which it differs in its more convex body (Figs 1-4), elytra microreticulate in posterior $1 / 3$, male genitalia having a narrow parallel penis (Fig. 5), and female gonocoxae much narrower (Fig. 6).

Description: Body (Fig. 1): length of male 5.0-5.4, of female 5.9-6.2 $\mathrm{mm}$ (anterior head margin to tip of elytra), maximum width of male $2.7-3.0$, of female $3.2-3.3 \mathrm{~mm}$; shape narrowly oval, length/ maximum width $1.8-2.0$; dorsal surface strongly convex in lateral view, reaching maximum height near middle (Fig. 3).

Dorsal side: Black with a bronze sheen laterally; scutellum not carinate; inner rows of elytral punctures some-

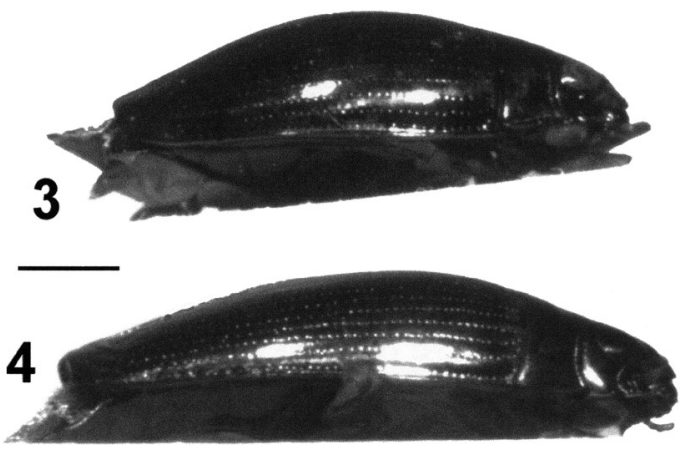

Figs. 3-4. Gyrinus, lateral habitus of male. - 3. G. sugunurensis sp. n., paratype. - 4. G. distinctus Aubé, Volgograd. Scale bar $1 \mathrm{~mm}$.

what weaker than outer rows; apical ellipsoid of punctures distinct; elytron with apical angle well-marked; micropunctation distinct; microreticulation with transverse meshes visible in posterior $1 / 3$ of elytron at $50 \times$ magnification, somewhat less distributed in male.

Ventral side: Black with hypomeron, epipleuron, mesosternum and fused gonocoxosternites (or sternum 8 ) reddish; mesosternum with narrow groove in posterior 2/5; metepisternal ostiole distinct.

Legs: Reddish yellow with tarsal claws not darker.

Genitalia: Penis subparallel, slightly narrower than paramere, ventrally carinate, apically pointed (Fig. 5); paramere with inner margin more or less straight; female gonocoxa rather short and wide, distal margin truncate, and basal margin without indentation (Fig. 6).

Etymology: The specific epithet is an adjective formed from the geographical name Sugu Nur.

Distribution: This species is seemingly restricted to Mongolia, and so far known only from the type locality and Ulan-Baator in the Central Province.

Habitat: According to the locality label, the type series was collected in a tributary to the river Haraa Gol. Consequently, the expected habitat is more slow-running parts of mountain streams.

\section{Taxonomic comments}

In the key to males of Nearctic Gyrinus species given by Oygur \& Wolfe (1991), G. sugunurensis will key out as G. pernitidus LeConte. The male genitalia of the two species are very similar, but G. sugunurensis differs in the more evident elytral micropunctation, larger body size, and less sinuately curved transverse pronotal line. Consequently, G. sugunurensis is not identical with any of the known Nearctic species of the genus. 
Figs. 5-6. Gyrinus sugunurensis sp. n., genital sclerites. -5 . Male. -6 . Female. Scale bar $0.5 \mathrm{~mm}$.

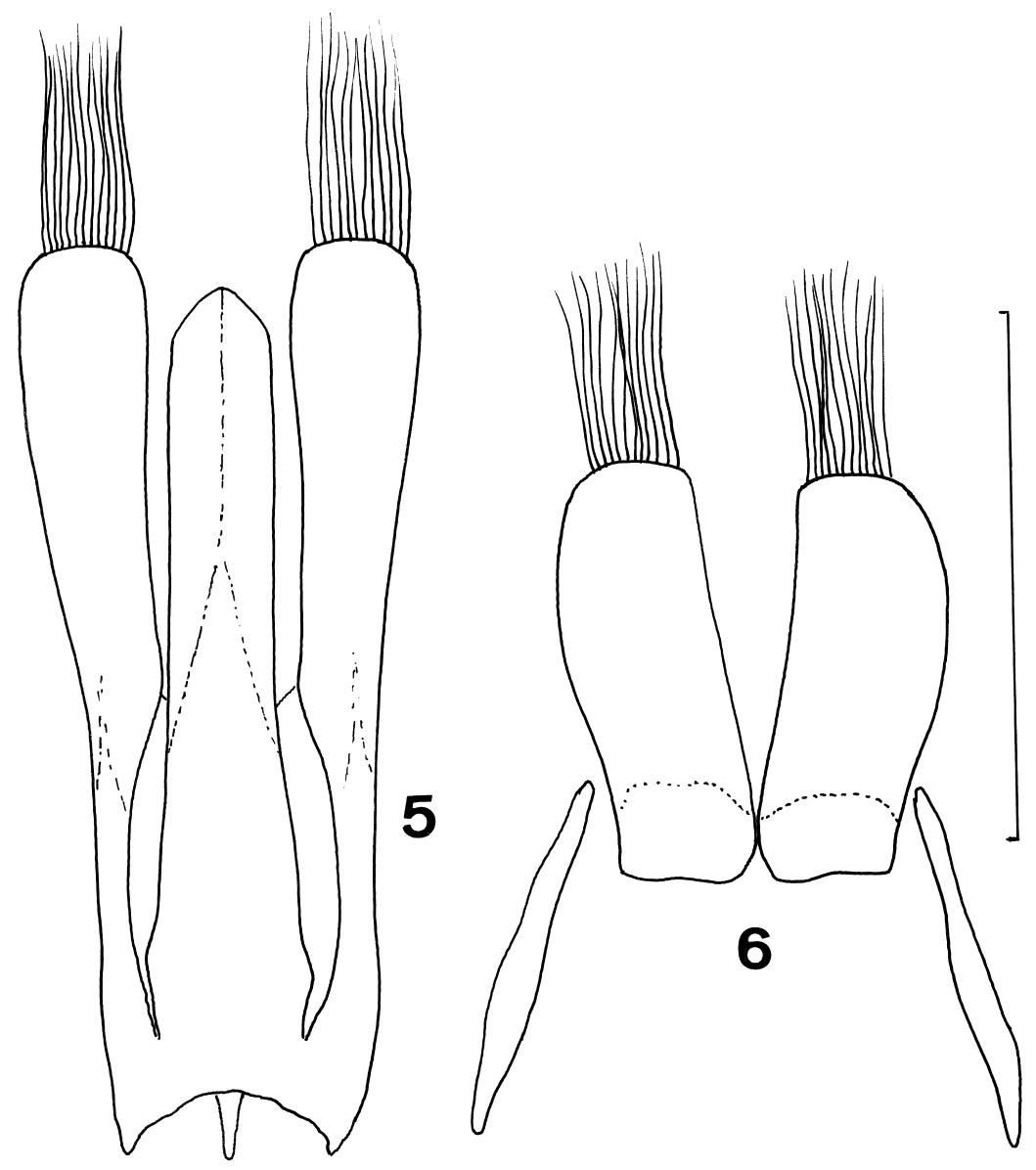

Acknowledgements. I thank Dr. A. G. Kirejtshuk, St. Petersburg, and Dr. O. Merkl, Budapest, for the loan of specimens. I also thank Dr. B. W. Svensson, Uppsala, for the comments he provided as referee.

\section{References}

Aubé, C. 1836-1838: Hydrocanthares. — In: Dejean, P. F. (ed.), Iconographie et histoire naturelle des Coléoptères d'Europe. Vol. 5. Paris. Méquignon-Marvis. 416 pp.

Guéorguiev, V. B. 1968: Coleoptera: Haliplidae, Dytiscidae, Gyrinidae II. Ergebnisse der zoologischen Forschungen von Dr. Z. Kaszab in der Mongolei. - Izvestija na Zoologitjeskija Institut s Musei Sofia 27: 23-29.

Guéorguiev, V. B. 1969: Dytiscidae et Gyrinidae (Coleoptera) de Mongolie. - Annales Zoologici Warszawa 27: 59-64.

Guéorguiev, V. B. 1972: Haliplidae, Dytiscidae, Gyrinidae IV. Ergebnisse der zoologischen Forschungen von Dr. Z. Kaszab in der Mongolei (Coleoptera). - Faunistische Abhandlungen staatliches Museum für Tierkunde in Dresden 4: 31-44.
Holmen, M. 1987: The aquatic Adephaga (Coleoptera) of Fennoscandia and Denmark. I. Gyrinidae, Haliplidae, Hygrobiidae and Noteridae. - Fauna Entomologica Scandinavica 20, $168 \mathrm{pp}$.

Méquignon, A. 1942a: Voyage de MM. L. Chopard et A. Méquignon aux Açores (août-septembre 1930). XIII. Diagnoses de Coléoptères nouveaux. — Bulletin de la Société Entomologique de France 47: 9-11.

Méquignon, A. 1942b: Voyage de MM. L. Chopard et A. Méquignon aux Açores (août-septembre 1930). XIV. Catalogue des Coléoptères Açoréens .- Annales de la Société Entomologique de France 111: 1-66.

Ochs, G. 1953: Ergebnisse der Österreichischen Iran-Expedition 1949/50. Gyrinidae (Coleoptera). - Sitzungsberichte der Österreichischen Akademie der Wissenschaften. Mathematisch-Naturwissenschaftliche Klasse, Wien 162, 4: 217-225.

Oygur, S. \& Wolfe, G. W. 1991: Classification, distribution and phylogeny of North American (North of Mexico) species of Gyrinus Müller (Coleoptera: Gyrinidae). - Bulletin of the American Museum of Natural History 207: 1-97.

Régimbart, M. 1883: Essai monographique de la famille 
des Gyrinidae. - Annales de la Société Entomologique de France (6)3: 121-190.

Régimbart, M. 1892: Essai monographique de la famille des Gyrinidae. 2. Supplément. Annales de la Société Entomologique de France 60(1891): 663-752.

Reitter, E. 1908: Fauna Germanica. Die Käfer des Deutschen Reiches. I. Band. - K. G. Lutz Verlag, Stuttgart. 248pp.

Seidlitz, G. 1887: Bestimmungs-Tabelle der Dytiscidae und Gyrinidae des europäischen Faunengebietes. - Verhandlungen des Naturforschenden Vereines in Brünn 25(1886): 3-136.

Sharp, D. 1914: The British species of Gyrinus. — The Entomologist's Monthly Magazine 50: 128-138.
Svensson, B. W. 1977: Dytiscidae and Gyrinidae (Coleoptera) from the Azores and Madeira. - Boletim do Museu Municipal do Funchal 31(137): 87-99.

Walt1, J. 1838: Beiträge zur Kenntniss der coleopteren der Türkei. - Isis Oken 6: 449-472.

Zimmermann, A. 1917: Der derzeitige Bestand der Gyrinidensammlung des Deutschen Entomologischen Museums in Berlin-Dahlem und die wissenschaftlichen Ergebnisse ihrer Durcharbeitung (Col.). — Entomologische Mitteilungen 6: 135-170.

Zimmermann, A. 1926: Synonymische Bemerkungen über einige Gyrinus-Arten. - Koleopterologische Rundschau 12: 97-98. 